\title{
Existentialist Temperament in African Drama: A Reading of Tewfik Al-Hakim's Plays
}

\author{
Oko Eze Ernest ${ }^{1}$, \& Chika Iwuoha-Chibueze ${ }^{2}$ \\ ${ }^{I}$ Department of English, University of Abuja, Nigeria \\ ${ }^{2}$ Department of English, University of Ibadan, Nigeria
}

\begin{abstract}
Many critical theories have developed over the years as a result of the complex nature of the modern world. There is a change from the colossal theories to more explicit ones, and existentialism is one of such theories. Existentialism is a concept which has been applied to the works of a group of nineteenth and twentieth century philosophers, thinkers, and writers, who share the belief that man's quest to determine the self in the modern world is met by hostility and indifference in a world bedevilled by war, oppression, strife, kidnapping, senseless killings, among others. The concept of existentialism is made popular in the works of Jean-Paul Sartre and Albert Camus, and most writers of this period wrote works of literature to capture the nothingness of life and equally demonstrate this unfortunate reality in the society. Findings reveal that existentialism appears relevant to the explication and criticism of these African dramas. Therefore, this essay seeks to explicate Tewfik Al-Hakim's plays: Fate of a Cockroach, The Song of Death, and Sultan's Dilemma, as existentialist dramas and concludes that, though, some of the plays under explication are humours and even absurd, they discuss and reiterate serious issues of life pertaining to man's search for independence.
\end{abstract}

Keywords: African Drama, Existentialism, Fate of a Cockroach, The Song of Death, Sultan's Dilemma, Tewfik Al-Hakim

\section{INTRODUCTION}

$\mathrm{L}$ iterature, across the globe, derives from man's interaction with his environment. It originates from man's conscious intent to express his feelings, responses and reactions to issues, that is, socio-political, socio-economic, spiritual and psychological issues of his time and society. Therefore, the literary artist, literature and society share a triadic relationship. This connectedness has its attendant effects on the artist, his art, and the society. This mode of interacting shows that literature plays a paradoxical role of providing pleasure and also providing the society with moral consequences of social actions and situations. This dual role is expanded by L.O Bamidele, in Oko (2010: 1):

By all means of style, metaphor, dazzling narrative technique, the humorous and the melodramatic that we could apply to reading and enjoying literature, the framework of the novel (fiction) will be a bad one if it bears no direct revelation to the social world, or as we say, if it does not reflect the reality of life as lived.
The above scholar's assertion buttresses the fact that literature especially that written by Africans, is a social phenomenon that springs from the creative consciousness of the writer. It must have a goal, which is to impact on the society. Therefore, AlHakim uses existentialist mode to impact on the society. This is what the paper seeks to interrogate in the context of Tewfik AlHakim's Fate of a Cockroach, The Song of Death, and Sultan's Dilemma.

\section{ORIGIN AND TENETS OF EXISTENTIALISM}

In the years following the World War II, the concept of existentialism gained many followers in France and elsewhere. The Existentialists argued that the universe contained no fixed and unchanging set of moral codes, and that each individual must create his/her own order and morality. The two leading proponents of this movement- JeanPaul Sartre and Albert Camus- were also important playwrights. Despite the postulation of an irrational universe, Sartre and Camus created dramas that essentially followed the traditional rules of rational construction and action. However, around 1950, a new group of dramatists, much influenced philosophically by Camus and Sartre, created a revolution in European drama by taking the irrational into the structure, motivation, and language of their plays. Although very different in style, these dramatists shared a rejection of the traditional cause-and-effect realistic drama, and as a group they came to be known as the Absurdist. The term comes from the 1942 essay by Albert Camus, The Myth of Sisyphus, which called the human condition absurd because humans continued to seek order and reason in a universe that was not built on those tenets.

The atrocities and evils of the World Wars destroyed the myth of man's rationality, and the belief in his ability to build a civilised world; but exposed his capacity for evil. Nationalism metamorphosed into hostility, slavery, concentration camps, massacres and genocide; the global social milieu was defined by an unprecedented eclipse of hope. There was a total breakdown of morality and other civilised values that formed the components of Western culture. A hitherto ordered world was suddenly and most tragically replaced by a chaotic and meaningless one. Man finds himself living in an alien universe in which he can neither come to terms with himself nor with his environment. In The Myth of Sisyphus, Camus went further to offer a most illuminating analysis of the situation. He reiterates thus: 
[A] World that can be explained even with a bad reason is a familiar world. But, on the other hand, in a universe suddenly divested of illusion and light, man feels a stranger. His exile is without remedy since he is deprived of the memory of a lost home or the hope of a promise land. This divorce between man and his life, the actor and his setting, is properly the feeling of absurdity (13).

However, existentialist tenets and themes are equally portrayed in the Theatre of the Absurd, notably in Beckett's Waiting for Godot (1954), in which two men divert themselves while they wait expectantly for someone (or something) named Godot who never arrives. They claim Godot to be an acquaintance but, in fact hardly know him. Osani (2007) observes that "there is a problem of man's irredeemable loss in a neutral universe that is constantly explored by the existentialist dramatist" (103). The emergence of the new dramatic practice is a significant landmark in the evolution of the modernist tradition of literature. And, modernism is a term which refers to a distinct, radical attitude to the human condition and a range of corresponding modes of expression in literature and arts. As Howe (1967) has observed, "a modernist culture is committed to the view that human lot is problematic" (18). There is no doubt that modernism is a growing culture as the problems of collapse of morality and the feeling of despair at inescapability of the human situation are fast becoming global realities. It is partly for this reason that one would hardly be surprised to find defining features of the Theatre of the Absurd in plays written by African writers. Writers globally are known to influence one another even across cultural or political boundaries or spaces. It is against this background that this paper seeks to examine Tewfik Al-Hakim's Fate of a Cockroach, The Song of Death, and Sultan's Dilemma as existentialist dramas.

\section{Fate of a Cockroach as an Existentialist Play}

The dramatist, Tewfik AL-Hakim, is popularly known for his creative prowess of using metaphors, symbols, and imageries to portray and lampoon the failed leadership and postcolonial disillusionment in his country, Egypt, nay Africa. But in these plays under study, he abandons established dramatic conventions and replaces them with radical experimental devices which are intended to express his thoughts and feelings in more concrete ways. Logical and well developed plot, realistic setting, life-like characters and the proper use of language, which are dominant features of the conventional or traditional plays, are discarded in this collection of plays. The dramatist deploys unusual dramatic procedure as he pays little or no attention to plot development, realistic characterisation, among others. The paper notices his melange or blend of animal and human characters side-by-side in Fate of a Cockroach. Esslin (1968) has succinctly explained that, "the existentialist drama strives to express its sense of the senselessness of the human condition and the inadequacy of the rational devices and discursive thoughts" (24). By employing experimental techniques, the writer intends to establish a consonance between thought and feeling and the mode of representation. Fate of a Cockroach has a somewhat universal dimension, while The Song of Death and Sultan's Dilemma, are rooted in the traditional or local culture of the Arabians' Islamic tradition.

A critical reading of these plays shows that they are imbued with elements and tenets of the Theatre of the Absurd in both content and style. But, Al-Hakim's conception of existentialist drama is different in these plays, that is, he does not follow the same mode of presentation in these plays under explication in this paper. More so, what runs through them as a recurring motif is the quest for freedom, that is, psychological freedom and that of physical. Nevertheless, the three plays depict the human condition in his quest to survive and determine the self in a world that is hostile and indifferent to the plight of his fellow man. Perturbed by the perplexities and contradictions of human life, writers of the Theatre of the Absurd constantly express the feeling that life is a bitter experience. In Beckett's Waiting for Godot, this feeling is overtly expressed. For instance, one of the two characters, Pozzo, laments that the "tears of this world are a constant quantity" (33); and Estragon, the second character, reveals that he has experienced happiness only in a dream (90). This feeling of unpleasantness of life is equally imbued in Fate of $a$ Cockroach. The excerpt below lends credence to this claim, thus:

King: Please, do not speak to the king in that tone!

Seek to entreat your queries with kindness and humility.

Queen: Then I would only ask kind sir, this humble question of royal highness- who made you king?

King: I made myself king.

Queen: And by what devious means and measures did you place yourself on the throne? (4)

We observe how the King Cockroach's attempt to appoint himself as king of the Cockroaches is frustrated by the indifference of his fellow Cockroaches. Even his wife, the Queen, does not respect his self-acclaimed (King) position and authority. The dialogue below between the King and the Queen aptly captures the notion of individualism, which is among the tenets of existentialism.

King: Please, withhold the sarcasm! I have a growing feeling that you've begun a campaign to belittle my worth.

Queen: Your worth?!

King: Yes, and to diminish my authority.

Queen: Your authority? Your authority over whom? Not over me at any rate. You are in no way better 
than me. You do not provide me with food or drink- I feed myself as you do- do you deny it?

King: In the whole of the Cockroach Kingdom, there is no Cockroach that feeds another. Everyone strives for his own bread.

Queen: Then I am free to do as I like? (3).

The above excerpt of dialogue between the King of Cockroach and his wife, the Queen, aptly captures existentialist temperament. Individualism is aptly portrayed here as even the king cockroach acknowledges the fact that "everyone strives for his own bread". In other words, an individual's existence and survival is determined only by factors akin to that individual, not by the actions or inactions of the others. Hence, the Queen interrogates and queries her husband (King) on his authority over her individuality. "Your authority? Your authority over whom?"(3). It clearly shows that, though, she (Queen) is his wife, the King does not have absolute power or authority over her personal wellbeing. The concept of individualism is what the playwright seems to demonstrate in this scene.

In this play, Fate of a Cockroach, man's natural love of freedom is not quantifiable, and his refusal to despair in the face of adversity, is reiterated in the Cockroach's striving to climb out of the bath, and this resonates with Adil's person; he is weighed down by the sharp realities of his life, the challenges of marriage; his constant scuffle with his wife and that of working in the establishment. The play is an amalgam of comic and political allegory. It begins with a self-appointed King of Cockroaches expounding the greatness of his achievement to indifferent compatriots while ants carry off individual Cockroaches for meals. The debate over Cockroach individualism and indifference towards one another, which are typical of the existentialist, is clearly captured in Act one, where an alarm is raised for the 'king' to be saved, having fallen into the bathtub. But the servant who is supposed to at all cost, save 'his master', summarily says:

No one can do so. He is in the very depths of the chasm

The walls are slippery. One's feet will slip on the smooth walls.

Only he can save himself, only by his own efforts- or a miracle from the skies! (25)

The above excerpt is an example of man's precarious fate in a world of hostility and indifferent, he is lonely even in the midst of people who ought to be his family. The statement, "only he can save himself, only by his own efforts - or a miracle from the skies" further confirms Howe's assertion that "human lot is problematic" (1967:18). Every human, at one time in his life time - if not throughout his life time - is subjected to or faced with one form of hostility or the other. And whenever this happens, the human is usually left alone in his struggle for deliverance and freedom despite his claim of possessing a superior intellect. The individualism of the cockroaches is contrasted in the play with the collective actions of the ants, which are able to subdue the cockroaches through collective discipline and cooperation. Though ants are smaller than cockroaches, a chain of ants can reduce the activities of cockroaches, and even other higher animals. This cockroach metaphor explicates the fact that the fate of the human is bedevilled by forces that, though they seem insignificant compared to the humans' superior intellect, are too powerful for him to deal with. The actions of the ants on the other hand as depicted in this play also show that there are more to be achieved if the humans are united and work as a team. More so, Adil fanatically watches a cockroach's futile attempt to climb out of the bathtub, this further dramatizes the futility of human nature. Adil feels he is alone in his struggle for freedom from his wife's dominance. And his wife, Samia, who controls her husband, grows increasingly concerned for his sanity. A domestic argument between Adil and his wife, Samia over who uses the bathroom first, leads to a question of the self by Adil, and this makes him identify himself with the struggle of the cockroach in the bathtub. The setting of fantastic with realistic events is imbued in the play. Al-Hakim creates a searing indictment on Egyptian leaders, and by extension, African leaders and even humanity at large. In the play, what is of most dramatic important is neither the physical action nor an evolving narrative sequence, but the absurd condition of a troubled couple- Adil and Samia- who argue over trivialities, as well as the 'royal' Cockroaches, who boast about non-existent achievements in the face of a more precarious reality of their existence that evoke Al-Hakim's thoughts about human condition. The activities of human and non-human characters in the play further deepen the existentialist temperament in the play. However, the lack of a sustained and purposeful action in the play does not mean that Al-Hakim lacks unity of vision, as the unity and meaning of Fate of a Cockroach, is neither in dialogue nor in physical action, but in the dominant symbols and pervasive images in the play, this actually lends credence to the tenet of existentialism. This mode of presentation is clearly in consonance with the usual form, construction, contention of plays of existentialist drama. Having clearly critiqued the existentialist temperament in the Fate of a Cockroach, it is pertinent at this juncture to consider the other two plays- The Song of Death and Sultan's Dilemma- that are within the scope of this paper.

The Song of Death is one of the other plays that is also considered in this paper, and the most local among the plays under explication. It is centred on the conflict between traditional retribution as much as a part of life in the rural Egypt as in Sicily, and liberty through education from such inhibiting and vicious prejudice. The Song of Death is a one act play that depicts the fraught and disillusioned atmosphere in Egypt. It centres on a family that awaits the return of the eldest son, a student in Cairo, in order that he may carry out a murder in response to the outlooks of a blood vendetta. 
The play has only four characters- Asakir; Mabrouka; Alwanm, the son of Asakir; and Sumeida, Mabrouka's son. Asakir seeks revenge on her husband's death and demands her son to kill Suweilam Tahawi, a man she believes killed her husband. Alwanm refuses to kill the man because he feels having been educated in the city he is supposed to be a change agent to his people and not to be the one that will avenge the death of his father on the man he is not even sure was the one that killed him. His refusal to avenge the death of his father clearly affirms the existentialist conception. That further explicates the idea of individualism, that is, he cannot fight or struggle for another individual, rather, for himself. He has acquired education, and that is a development of oneself. Alwanm feels there is no sense in retaliated killing, which has resulted in a downward spiral of the relationship between the two families for over seventeen years. His mother (Asakir) is obstinate to let her son have his way; she is already possessed by the fad of blood-letting and senseless killing between these two families. This act further deepens the destructive tendency of human nature. Al-Hakim uses this to lampoon and show the irrationality and destructive nature of man. We even observe in the play that Asakir could not even tell her son the remote cause of this age-old rivalry between these families. In the end, her son's refusal to join in this vengeful act of killing Suweilam Tahawi leads to his own death as Asakir orders Sumeida to kill her own son before he (Alwanm) leaves for Cairo. The other three characters-Asakir, Mabrouka, and Sumeida- except Alwanm, live in a world where qualities that make us humans are lacking, that is, a world where hunger and thirst for vengeance have replaced the desire for food and drink. Asakir's husband was killed seventeen year ago, she opts to "twist and turn on a fire of rage" (84) for that long, waiting for the time her son would attain manhood and quench her thirst for vengeance with the blood of the suspected murderer, Suweilam. Her society dictates to her that it is shameful and an act of cowardice to report a crime as grave as murder to the authorities, rather that dignity and pride come from relentless lust for violence, unfounded hatred and taking of laws into one's hands. The play portrays and dramatises the irrationality, callousness, and destructive nature of man. Man is seen to be spiteful and exacting in the play, which underscores the existentialist temperament. The character of Asakir is likened to cruelty, insincerity, cannibalism, and destructiveness of leaders in Africa, and globally. The last play to be considered in this paper is the Sultan's Dilemma, which has imaginary setting and simple plot, is also imbued with existentialist temperament. As reiterated earlier in this paper, it is rooted in the traditional or local culture of the Arabians' Islamic tradition. The author uses the play to question contemporary challenges in the world, more importantly, in Egypt, nay, Africa.

The Sultan's Dilemma is set in the 'Thousand and One Nights' atmosphere of the rule of a Mameluke sultan. Freedom and choice faced by the ruler are the central preoccupations. The historical antecedents in the play were concrete for the Egyptian audience when the play was published in 1960, and this coincides with the regime of Mameluke sultan. The author's growth as a dramatist in which he uses his mode of presentation to lampoon and interrogate topical contemporary issues in his immediate society, Egypt, and Africa at large, marks him out. The play is set in an earlier Egyptian history and Al-Hakim uses it to illuminate on his people's culture. He clearly explores the issue of legitimisation of power. A king at the height of his position or power, is suddenly faced with the fact that he has never been manumitted and that thus ineligible to be a ruler.

As at the time when this play was published in 1960, some of the initial euphoria and hope that were engendered by the government, whose regime itself had given expression in, had begun to fade. The Egyptians found them confronting some unsavoury realities and postcolonial disillusionments that are common to most African states; characterised by the use of the secret police to crush the public expression of opinion - for instance, the personality cult surrounding the figure of the military head of state. In such a historical context, Al-Hakim's play can be seen as a somewhat courageous statement of the need for even the mightiest to adhere to the laws of the land, and specifically a plea to the then ruling military regime to eschew the use of violence and instead seek legitimacy through the application of the rule of law. The universality of 'fate' in human existence is seen in series of events that unfold around the Sultan. He, in a very quick twist of destiny moves from being a powerful Sultan to an article of commercial value - a slave; and back to a Sultan again through sheer luck and ingenuity and magnanimity of a woman, seen as a social non-conformist, a whore. Whereas her love for the art and the all enduring desire for 'freedom' is what gives her social stigma, the play strongly interrogates the legal institution, as justice is seen to have an eye with a bid to manipulate and exploit unsuspecting individuals. The excerpt below actually illuminates this temperament, thus:

Vizier: Do you think a trick like this will put matters right?

Cadi: Yes, in the best way possible. Tonight I set about considering every aspect of the matter.

I still have in my quiver-or, to be more exact, in the law's quiver- many tricks.

The dialogue above captures how the law is manipulated and justice perverted for selfish ends. In other words, the law that should serve justice to the ordinary citizens is manipulated at will by the custodians to work against the people it should protect. The playwright, Al-Hakim, also mocks the religious institution in Egyptian society, nay Africa. He equally lampoons the Islamic practice as the Muezzin is asked to call for morning prayers at midnight. It is also an indictment on the citizenry who are myopic and partial in dealing with issues pertaining to gender and equality of the sexes. The existentialists consider the role of making free choices paramount. This is particularly regarding fundamental values and beliefs; such choices change the nature and identity of the 
person in the society. Such person is seen as a social misfit. We observe in the Sultan's Dilemma in the character of the lady who is considered a 'whore' because of her life style. Her love for arts and the company of men of great minds stands her apart in a society that is highly religiously fanatical and socially patriarchal. Though the play could be seen to have ended on a happy note, the playwright, Al-Hakim, uses it to depict existentialist temperament.

\section{CONCLUSION}

This paper has critically examined the three plays by Tewfik AL-Hakim: Fate of a Cockroach, The Song of Death, and Sultan's Dilemma. These plays represent the contention of this essay, that is, explication of the existentialist temperament in the texts. Therefore, the paper has demonstrated the relevance of the concept of existentialism to the assessment of African drama. The survey reviewed the core issues relating to the theory of existentialism- origin and the tenets. Textual illustrations and examples are drawn from the three plays used in this study to examine how the theory of existentialism evolves through the chosen texts. The study has discovered that the plays are fore-grounded with the theory of existentialism.

It seems correct, therefore, to conclude that, features which define the dramas of the absurdist theatre are the same ones that predominate in these plays considered in this study, these are; underdeveloped plot, illogical dialogue among characters, and other experimental devices. Thus, the paper affirms that Al-Hakim's plays treated in this essay are existentialist as they all bring to bear the elusiveness of man's search for freedom and survival in a world of abhorrence, chauvinism and injustice.

\section{WORKS CITED}

[1] Al- Hakim, Tewfik. 1966. Fate of a Cockroach and Other Plays. Trans. D. Johnson-Davies. London: Heinemann.

[2] Beckett, Samuel. 1965. Waiting for Godot. London: Faber and Faber.

[3] Camus, Albert. 1942. The Myth of Sisyphus. Harmondsworth: Penguin.

[4] Esslin, M. 1968. The Theatre of the Absurd. Harmondsworth: Penguin.

[5] Howe, Irving. Ed. 1967. The Idea of the Modern in Literature and the Arts. New York: Horizon Press.

[6] Oko Eze, Ernest. 2010. Animism in Ben Okri's The Famished Road and Songs Enchantment. An M. A. Thesis Department of English, University of Ibadan. $\mathrm{x}+71 \mathrm{pp}$.

[7] Osani, Dumebi. 2007. Clarke Bedekeremo's The Raft as an Absurdist Drama. Papers in English and

[8] Linguistics (PEL). Ife: $\operatorname{Vol} 7$ \& 8.99 - 108.

[9] Sartre, Jean-Paul. 1975. Existentialism is a Humanism. Existentialist from Dostoevsky to Sartre. Walker Kaufmann. Ed. New York: American Library Inc. 345 - 369.

\section{AUTHORS' PROFILE}

OkoEze, Ernest is a doctoral student at the Department of English, University of Abuja, Nigeria. His areas of interest are African literature, literary theory, and African oral tradition.He critiques African prose fiction dealing with disillusionment in Post-independence Africa.

Chika Iwuoha-Chibueze is also a doctoral student at the Department of English, University of Ibadan. She focuses mainly on the critiques of African drama, especially those dealing with African Post-colonial realities. 


\section{Authors' profile:}

Oko Eze, Ernest is a doctoral student at the Department of English, University of Abuja, Nigeria. His areas of interest are African literature, literary theory, and African oral tradition. He critiques African prose fiction dealing with disillusionment in Post-independence Africa.

Email: docernestoh2@gmail.com.

Chika Iwuoha-Chibueze is also a doctoral student at the Department of English, University of Ibadan. She focuses mainly on the critiques of African drama, especially those dealing with African Post-colonial realities.

Email: prechyke7ng@yahoo.com. 